\title{
Analisis THD dan Peningkatan Arus pada Kawat Netral Akibat Pengoperasian Beban Non Linier yang Tak Seimbang pada Sistem Tenaga Listrik di RSUD Kabupaten Klungkung
}

\author{
I Gusti Ngurah Dwipayana ${ }^{1}$, I Wayan Rinas ${ }^{2}$, I Made Suartika ${ }^{3}$
}

\begin{abstract}
Harmonics lead to distortion by waves, currents and voltages. The imbalance of the load on the electrical system will affect the percentage of harmonics in the system and will also affect the value of neutral current (IN). The simulation results that have been carried out under a linear load balanced with neutral current value is 0 . In the condition is not balanced by a linear load value of neutral current is $45.76 \mathrm{~A}$. In the balanced condition with non-linear load 61.62 A neutral current value with the percentage THDv in phase $R 1.49 \% ; S 1.47 \%$; $T 1.48 \%$ and THDi in phase $R 16.38 \%$; $S 16.31 \%$; $T$ 16.19\%. In the condition is not balanced by an increase in non-linear load value neutral current 65.5 A with a percentage THDv on phase $R 1.61 \%$; $S$ $1.49 \%$; $T$ 1.46\% and THDi in phase $R 18.47 \%$; $S 16.57 \%$; $T$ $15.84 \%$.
\end{abstract}

Intisari- Harmonisa mengakibatkan terjadinya distorsi pada gelombang arus dan tegangan. Ketidakseimbangan beban pada sistem kelistrikan akan mempengaruhi prosentase harmonisa pada sistem tersebut dan juga akan berpengaruh terhadap nilai arus netral $\left(I_{N}\right)$. Hasil simulasi yang telah dilakukan pada kondisi seimbang dengan beban linier nilai arus netral adalah 0 . Pada kondisi tak seimbang dengan beban linier nilai arus netral adalah 45,76 A. Pada kondisi seimbang dengan beban non linier nilai arus netral 61,62 A dengan prosentase THDv pada fasa $R$ $1,49 \%$; $S 1,47 \%$; $T$ 1,48\% dan THDi pada fasa $R 16,38 \%$; $S$ $16,31 \%$; T 16,19\%. Pada kondisi tak seimbang dengan beban non linier terjadi peningkatan yaitu nilai arus netral 65,5 A dengan prosentase THDv pada fasa $R 1,61 \%$; $S 1,49 \%$; $T$ $1,46 \%$ dan THDi pada fasa R $18,47 \%$; $S 16,57 \%$; T $15,84 \%$.

Kata Kunci-Harmonisa, Ketidakseimbangan beban, Arus netral.

\section{Pendahuluan}

Keadaan tak seimbang merupakan keadaan dimana salah satu syarat dari keadaan seimbang tidak terpenuhi yaitu : ketiga vektor sama besar tetapi tidak membentuk sudut $120^{\circ}$, ketiga vektor tidak sama besar tetapi membentuk sudut $120^{\circ}$ atau ketiga vektor tidak sama besar dan tidak membentuk sudut $120^{\circ}$. Ketidakseimbangan beban pada tiap fasa mengakibatkan adanya arus yang mengalir pada kawat netral. Beban non linier mengakibatkan terjadinya distorsi pada gelombang arus dan tegangan yang disebut harmonisa.

\footnotetext{
${ }^{1}$ Mahasiswa Teknik Elektro, Fakultas Teknik Universitas Udayana, Jln.Kampus Bukit Jimbaran 80361 INDONESIA (telp: 0361-703315; e-mail: igstngrdwipayana@yahoo.co.id

${ }^{2,3}$ Dosen Teknik Elektro Fakultas Teknik Universitas Udayana, Jln.Kampus Bukit Jimbaran 80361 INDONESIA (telp: 0361703315; fax: 0361-703315; e-mail: $2{ }^{2}$ rinas@unud.ac.id, suartika@ee.unud.ac.id
}

Harmonisa pada suatu sistem tenaga listrik dapat mengakibatkan berkurangnya kinerja dari suatu peralatan, mengurangi umur peralatan tersebut, overheating pada transformator, dan mengganggu kinerja dari penghantar netral karena adanya arus yang mengalir.

Sistem kelistrikan RSUD Kabupaten Klungkung mengoperasikan 2 buah transformator distribusi $20 \mathrm{kV} / 400 \mathrm{~V}$ dengan kapasitas masing-masing sebesar 197 kVA. Kedua transformator tersebut masing-masing memiliki 1 buah MDP (Main Distribution Panel) yang kemudian dibagi dalam 18 buah SDP (Sub-Distribution Panel). Penelitian ini hanya membahas pada transformator 1 , penelitian ini melakukan pengukuran THD tegangan (THDv dan THD arus (THDi) saat beban puncak pada tiap-tiap MDP yang terpasang. Hasil pengukuran yang diperoleh akan dibandingkan dengan standar IEEE 519 tahun 2014 yang dijadikan sebagai acuan analisis. Setelah dilakukan pengukuran awal diketahui bahwa THDv pada transformator 1 yaitu pada fasa $R=1,52 \%$ fasa $S=1,52$ $\%$ fasa $\mathrm{T}=1,49 \%$. Sedangkan THDi pada transformator 1 yaitu pada fasa $R=17,19 \%$ fasa $S=15,28 \%$ fasa $T=17,71$ \%. Berdasarkan standar IEEE 519 tahun 2014, batasan THDv yang diperbolehkan pada sistem dengan tegangan nominal dibawah $1 \mathrm{kV}$ yaitu $\mathrm{THD}_{\mathrm{V}} 8 \%$ sehingga diketahui bahwa THDv pada transformator 1 yang terukur masih sesuai dengan standar yang ditetapkan. Sedangkan THDi sesuai standar IEEE 519-2014, dengan $\mathrm{SC}_{\text {ratio }} 25,07$ standar THDi yang digunakan yaitu THDi $8 \%$ sehingga diketahui bahwa THDi pada transormator 1 yang terukur tidak sesuai dengan standar yang ditetapkan.

\section{TINJAUAN PUSTAKA}

A. Asymetri

Faktor-faktor dibawah ini dapat memunculkan arus dan tegangan asymetri [3]:

1. Beban industri 1 fasa.

2. Beban 1 fasa di area pertokoan dan pedesaan.

3. Perbedaan dalam resistansi fasa dan reaktansi beberapa beban.

4. Perbedaan impedansi sendiri dan bersama pada jalur supplai.

5. Busur api dan beban tidak simetris lainnya.

Saat terjadi asymetri tegangan maupun arus akan berdampak penurunan umur isolasi sebagai efek loses tambahan dan kenaikan temperature, bertambahnya kebutuhan reaktif power, berkurangnya kapasitas reaktif power, berkurangnya power factor. 


\section{B. Arus Netral}

Arus netral pada sistem distribusi merupakan arus yang mengalir pada penghantar netral pada sistem tiga fasa empat kawat. Munculnya arus netral dapat disebabkan karena ketidakseimbangan beban dan juga karena adanya arus harmonisa sebagai akibat banyaknya penggunaan beban nonlinier.

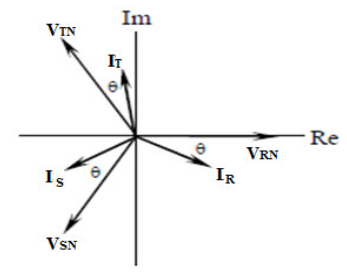

Gambar 1. Fasor Tegangan dan Arus Untuk Beban Terhubung Bintang.

Dari gambar fasor di atas dapat dilihat bahwa jumlah arusarus fasa adalah:

$\mathrm{I}_{\mathrm{R}}+\mathrm{I}_{\mathrm{S}}+\mathrm{I}_{\mathrm{T}}=0$

Untuk titik netral maka persamaanya :

$\mathrm{I}_{\mathrm{N}}+\mathrm{I}_{\mathrm{R}}+\mathrm{I}_{\mathrm{S}}+\mathrm{I}_{\mathrm{T}}=0$

Maka,

$\mathrm{I}_{\mathrm{N}}=-\left(\mathrm{I}_{\mathrm{R}}+\mathrm{I}_{\mathrm{S}}+\mathrm{I}_{\mathrm{T}}\right)=0$

3 fasa 4 kawat yang terhubung bintang, karena adanya Sistem 3 fasa 4 kawat yang terhubung bintang, karena adanya ketidakseimbangan beban maka, akan ada arus yang mengalir pada penghantar netralnya.

Pada keadaan tak seimbang terdapat komponen urutan nol pada penghantar netralnya. Persamaan arus netralnya dapat ditulis sebagai berikut :

$\mathrm{I}_{\mathrm{N}}=\mathrm{I}_{\mathrm{R}}+\mathrm{I}_{\mathrm{S}}+\mathrm{I}_{\mathrm{T}}=3 \mathrm{I}_{0}$

Arus netral yang tinggi dapat mempengaruhi sistem, berikut ini merupakan pengaruh yang dapat disebabkan oleh arus netral yaitu timbulnya panas berlebih pada transformator, menurunnya kwalitas daya.

\section{Beban Linier dan Non Linier}

Beban yang gelombang keluarannya sebanding dengan tegangannya dalam tiap setengah siklus yang mengakibatkan gelombang keluarannya sama dengan gelombang masukannya baik gelombang arus maupun tegangan disebut dengan beban linier [2]:. Bentuk gelombang tegangan dan arus ditunjukkan pada gambar 2 .

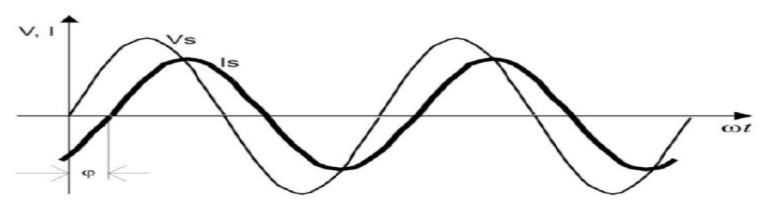

Gambar 2 Bentuk Gelombang Arus dan Tegangan Beban Linier

Beban non linier merupakan beban yang gelombang keluarannya tidak sebanding dengan tegangan dalam setiap setengah siklus, maka bentuk gelombang arus maupun tegangan keluarannya tidak sama dengan gelombang masukannya [2]. Walaupun disuplai dari tegangan yang sinusoidal beban non linier tetap akan menarik arus yang tidak sinusoidal. Bentuk gelombang tegangan dan arus ditunjukkan pada gambar 3 .

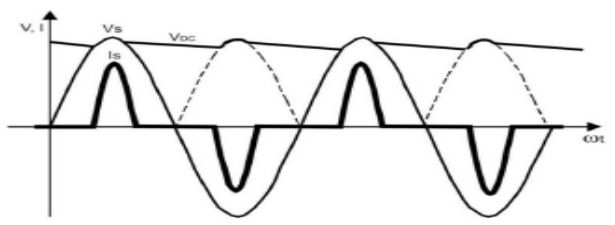

Gambar 3 Bentuk Gelombang Arus dan Tegangan Beban Non Linier

\section{Harmonisa}

Pada dasarnya, harmonisa merupakan gejala pembentukan gelombang yang berbeda dengan gelombang fundamentalnya. Harmonik menurut International Electrotechnical Commision (IEC) 6100-2-1- 1990 didefenisikan sebagai tegangan ataupun arus sinusoidal yang mempunyai kelipatan frekuensi sistem pasokan tenaga listriknya sebagaimana yang dirancang untuk dioperasikan ( $50 \mathrm{~Hz}$ ataupun $60 \mathrm{~Hz}$ ). Mirip dengan IEC, Institute of Electrical and Electronic Engineering (IEEE) Std 1159-1995 mendefenisikan harmonik sebagai tegangan ataupun arus sinusoida yang mempunyai kelipatan bulat dari frekuensi dimana system tenaga listrik pasokannya dirancang untuk dioperasikan (atau disebut juga dengan terminology : frekuensi fundamental, yaitu pada umumnya $50 \mathrm{~Hz}$ atau 60 $\mathrm{Hz}[3]:$.

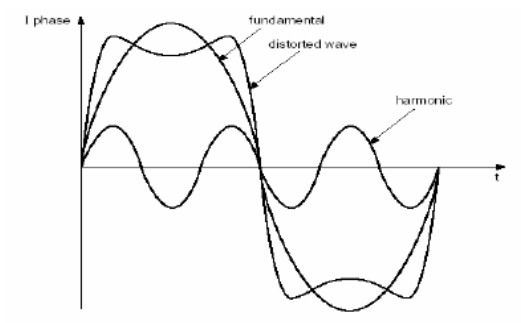

Gambar 4 Gelombang Fundamental, Gelombang Harmonisa dan Gelombang Terdistorsi

\section{E. Total Harmonic Distortion (THD)}

THD merupakan rasio antara nilai rms dari komopnenkomponen harmonisa dan nilai rms fundamentalnya. THD berlaku untuk tegangan dan arus [2]:

$\operatorname{THD}_{\mathrm{i}}=\frac{\sqrt{\sum_{\pi}^{\infty}=2 !_{h}^{2}}}{I_{1}}$

Dengan persamaan yang sama THD untuk tegangan dapat ditentukan dengan persamaan di bawah ini.

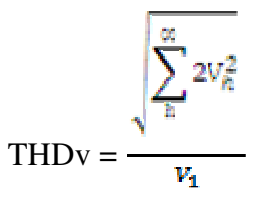

I Gusti Ngurah Dwipayana: Analisis THD dan Peningkatan Arus ...

p-ISSN:1693 - 2951; e-ISSN: 2503-2372 
Keterangan :

$\mathrm{THD}_{\mathrm{i}}, \mathrm{THD}_{\mathrm{v}}=$ total harmonik distortion arus atau tegangan.

$\mathrm{V}_{\mathrm{h}} \quad=$ nilai rms tegangan harmonik ke-h.

$\mathrm{I}_{\mathrm{h}} \quad$ = nilai rms arus harmonik ke-h.

$\mathrm{V}_{1} \quad=$ nilai $\mathrm{rms}$ tegangan pada frekuensi dasar.

$\mathrm{I}_{1} \quad=$ nilai rms arus pada frekuensi dasar.

Hasil perhitungan THDv dan THDi sebaiknya tidak melebihi standar yang berlaku karena akan membahayakan komponen-komponen system.

F. Standar Harmonisa Berdasarkan IEEE 519-2014 [4].

TABEL I

STANDAR THDv IEEE $519-2014$

\begin{tabular}{|c|c|c|}
\hline Bus Voltage (V) at PCC & $\begin{array}{c}\text { Individual } \\
\text { Harmonic (\%) }\end{array}$ & $\begin{array}{c}\text { Total Harmonic Distortion } \\
(\%)\end{array}$ \\
\hline $\mathrm{V} \leq 1 \mathrm{Kv}$ & 5.0 & 8.0 \\
\hline $1 \mathrm{kV}<\mathrm{V}<69 \mathrm{Kv}$ & 3.0 & 5.0 \\
\hline $69 \mathrm{kV}<\mathrm{V}<161 \mathrm{kV}$ & 1.5 & 2.5 \\
\hline $161 \mathrm{kV}<\mathrm{V}$ & 1.0 & 1.5 \\
\hline
\end{tabular}

TABEL II

STANDAR THDI IEEE 519 - 2014

\begin{tabular}{|c|c|c|c|c|c|c|}
\hline \multicolumn{7}{|c|}{ Maximum Harmonic Current Distortion in Percent of $\mathrm{I}_{\mathrm{L}}$} \\
\hline \multicolumn{7}{|c|}{ Individual Harmonic Order (odd harmonic) } \\
\hline $\mathrm{I}_{\mathrm{SC} / \mathrm{L}}$ & $\begin{array}{c}3 \leq \mathrm{h} \leq \\
11\end{array}$ & $\begin{array}{c}11 \leq \mathrm{h} \\
\leq 17\end{array}$ & $\begin{array}{c}17 \leq \mathrm{h} \\
\leq 23\end{array}$ & $\begin{array}{c}23 \leq \mathrm{h} \\
\leq 35\end{array}$ & $\begin{array}{c}35 \leq \mathrm{h} \\
\leq 50\end{array}$ & $\begin{array}{c}\mathrm{THD} \\
(\%)\end{array}$ \\
\hline$<20^{\mathrm{c}}$ & 4.0 & 2.0 & 1.5 & 0.6 & 0.3 & 5.0 \\
\hline $20<50$ & 7.0 & 3.5 & 2.5 & 1.0 & 0.5 & 8.0 \\
\hline $\begin{array}{c}50< \\
100\end{array}$ & 10.0 & 4.5 & 4.0 & 1.5 & 0.7 & 12.0 \\
\hline $100<$ \\
1000
\end{tabular}

\section{G. Pemodelan dan Sistem}

Komponen-komponen yang digunakan dalam gambar pemodelan sistem di atas yaitu sebagai berikut:

- Three-Phase source adalah Sumber tiga phasa.

- Three-Phase V-I Measrument supply adalah Alat ukur parameter sumber tiga phasa.

- $\quad$ Three-Phase V-1 Measrument Load adalah Alat ukur parameter beban tiga phasa.

- Nonlinier Load 1,2, \& 3 adalah subsystem beban nonlinier yang terpasang.

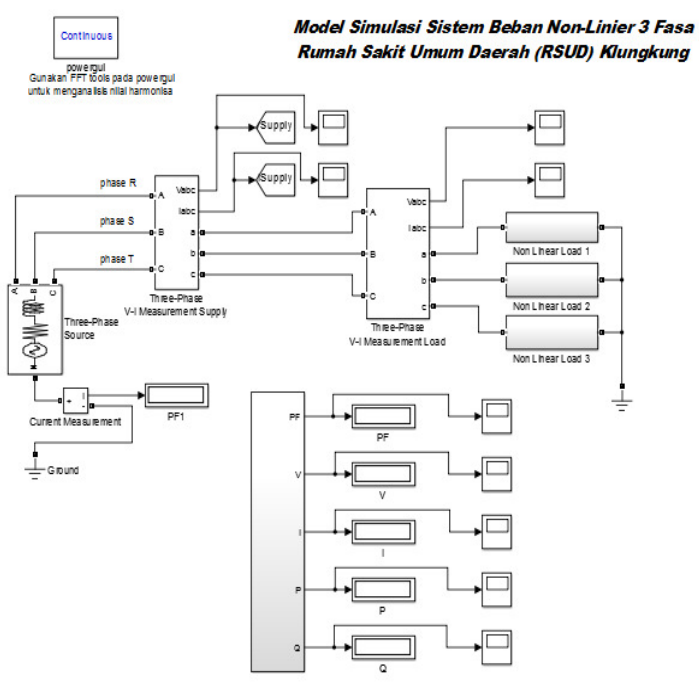

Gambar 5 Model Sistem Beban

- Display adalah Media untuk menampilkan parameter-parameter simulasi berupa angka.

- Display PF1 adalah Media untuk menampilkan simulasi Arus Netral berupa angka.

- Scope adalah Media untuk menampilkan parameterparameter simulasi gelombang.

- $\quad$ Powergui adalah simulasi spektrum $\mathrm{V}_{\mathrm{THD}}$ dan $\mathrm{I}_{\mathrm{THD}}$ dengan menggunakan Fast Fourier Transform (FFT) tools.

\section{METODE PENELITIAN}

A. Alur Analisis

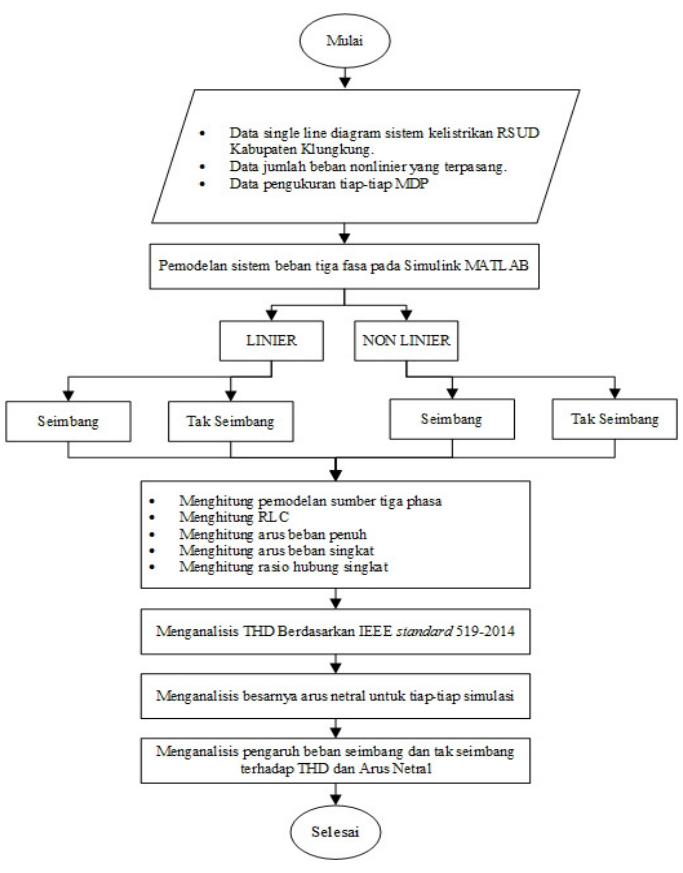

Gambar 6 Diagram Alir (Flowchart) 


\section{HASIL DAN ANALISIS}

\section{A. Hasil Simulasi Total Harmonic Distortion}

Dengan menggunakan metode FFT, diperoleh hasil simulasi THDv dan THDi seperti yang ditunjukkan pada gambar 7 sebagai berikut :

\section{Beban Linier}

- Beban Linier Untuk Kondisi Seimbang

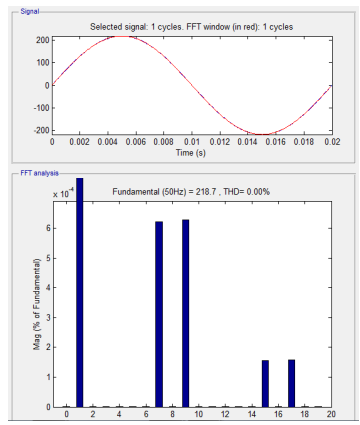

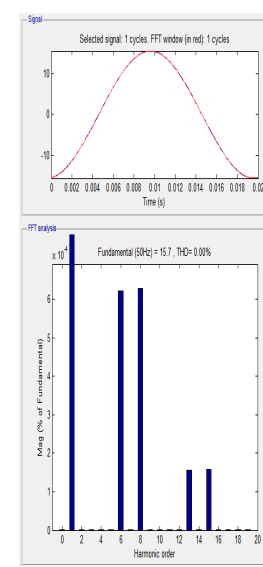

(a)
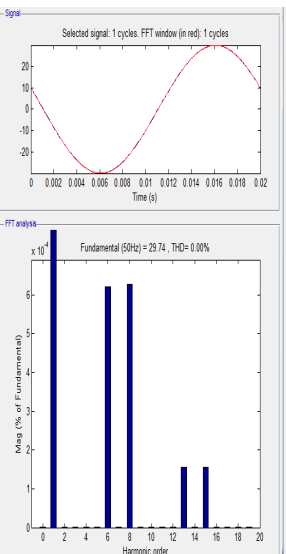

(b)

(c)
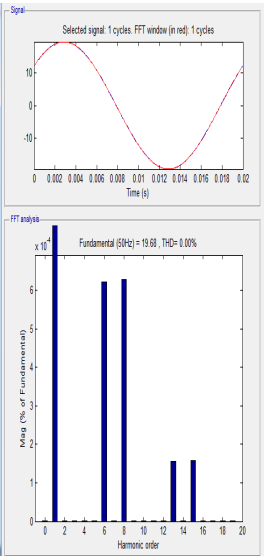

Gambar 10 Gelombang dan Spektrum THDi (a) phasa R, (b) phasa S, (c) phasa $\mathrm{T}$.

\section{Arus Netral Untuk Beban Linier}

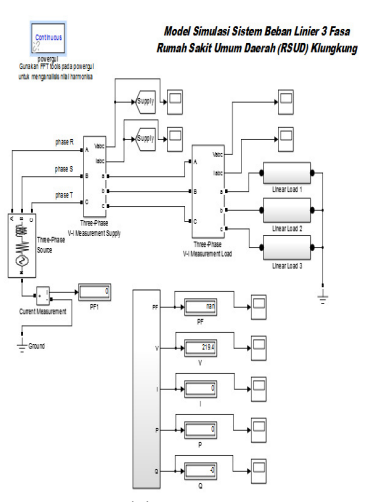

(a)

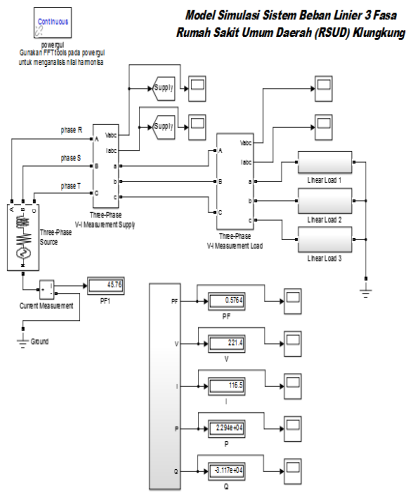

(b)

Gambar 11 (a) Arus netral yang muncul pada kondisi seimbang. (b) Arus netral yang muncul pada kondisi tak seimbang.

\section{Beban Non Linier}

- Beban Non Linier Untuk Kondisi Seimbang

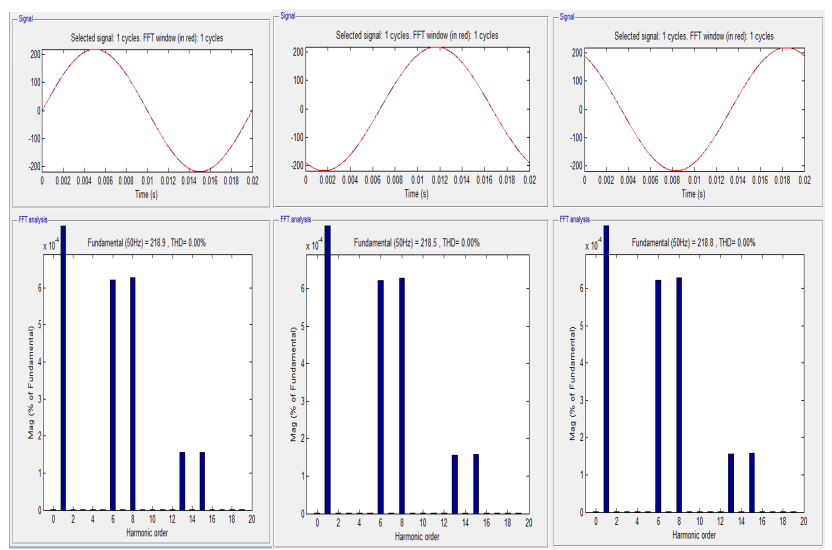

(a)

(b)

(c)

Gambar 9 Gelombang dan Spektrum THDv (a) phasa R, (b) phasa S, (c) phasa $\mathrm{T}$

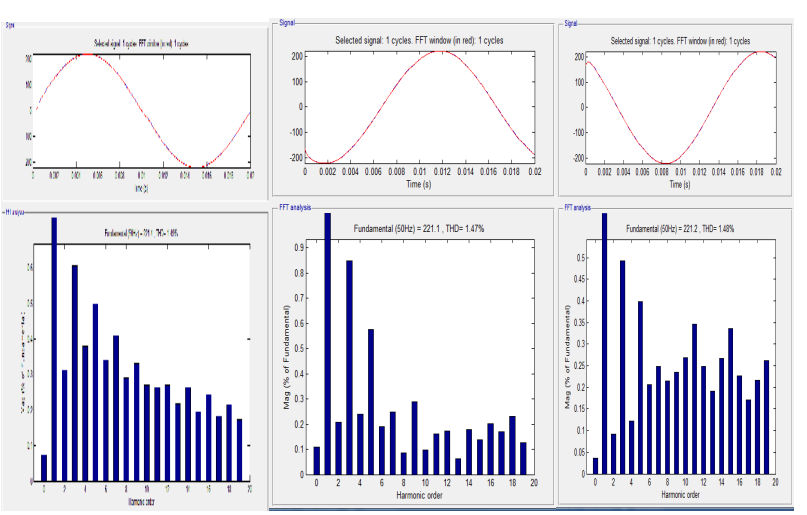

(a) (c)

Gambar 12 Gelombang dan Spektrum THDv (a) phasa R, (b) phasa S, (c) phasa $\mathrm{T}$

p-ISSN:1693 - 2951; e-ISSN: 2503-2372

I Gusti Ngurah Dwipayana: Analisis THD dan Peningkatan Arus ... 


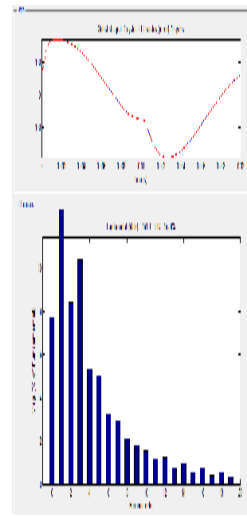

(a)
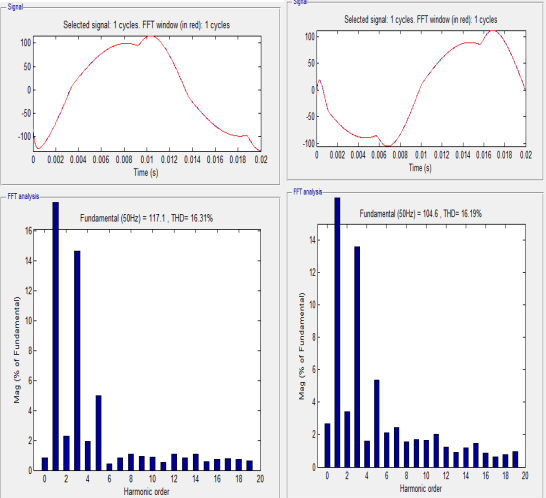

(b)

Gambar 13 Gelombang dan Spektrum THDi (a) phasa R, (b) phasa S, (c) phasa $\mathrm{T}$.

\section{- Beban Non Linier Untuk Kondisi Tak Seimbang}

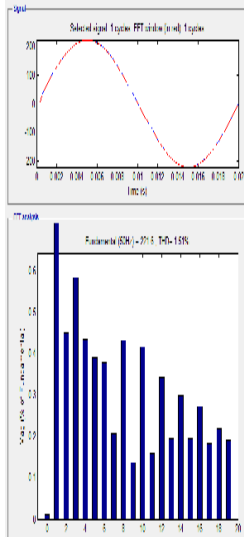

(a)

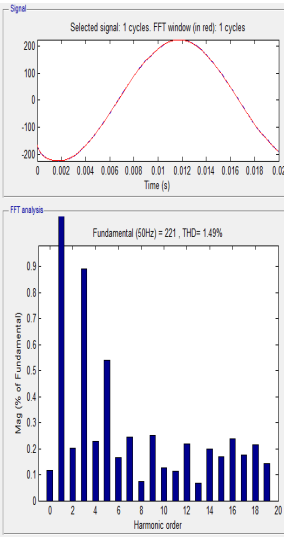

(b)

(c)

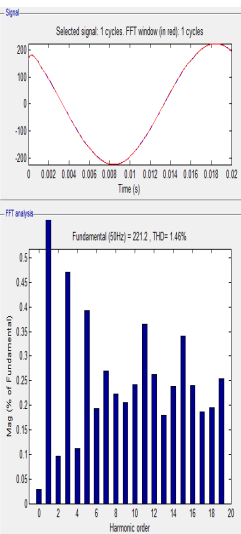

Gambar 14 Gelombang dan Spektrum THDv (a) phasa R, (b) phasa S, (c)

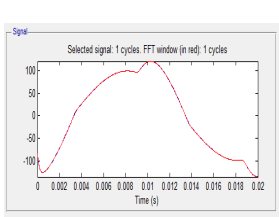
phasa $\mathrm{T}$

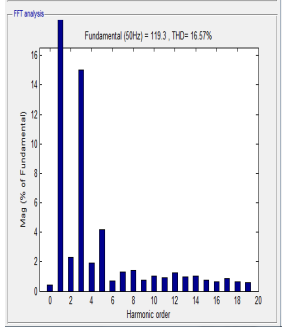

(a)

(b)

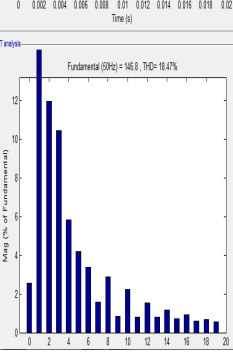

(c)
Gambar 15 Gelombang dan Spektrum THDi (a) phasa R, (b) phasa S, (c) phasa $\mathrm{T}$.

\section{Arus Netral Untuk Beban Non Linier}

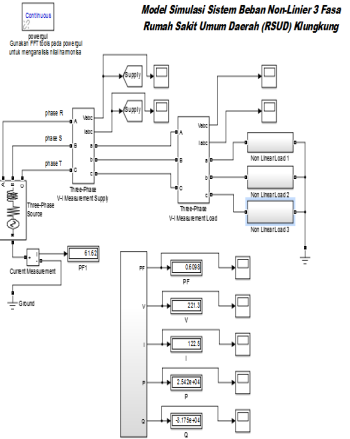

(a)

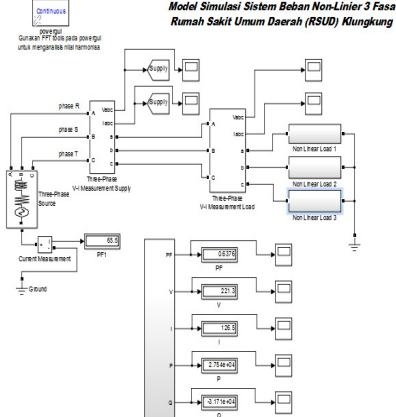

(b)
Gambar 16 (a) Arus netral yang muncul pada kondisi seimbang. (b) Arus netral yang muncul pada kondisi tak seimbang.

TABEL III

HASIL SimUlasi THDv, THDi, DAN ARUS NETRAL

\begin{tabular}{|c|c|c|c|c|c|c|c|}
\hline \multirow{2}{*}{$\begin{array}{c}\begin{array}{c}\text { Jenis } \\
\text { beban }\end{array} \\
\text { Linier }\end{array}$} & \multicolumn{3}{|c|}{ THD Tegangan $\%$} & \multicolumn{3}{|c|}{ THD Arus \% } & \multirow{2}{*}{$\begin{array}{c}\text { Arus } \\
\text { Netral } \\
\text { (A) }\end{array}$} \\
\hline & $\mathbf{R}$ & $\mathbf{S}$ & $\mathbf{T}$ & $\mathbf{R}$ & $\mathbf{S}$ & $\mathbf{T}$ & \\
\hline $\begin{array}{c}\text { Simulasi } \\
\text { Seimbang } \\
\%\end{array}$ & 0 & 0 & 0 & 0 & 0 & 0 & 0 \\
\hline $\begin{array}{c}\text { Simulasi } \\
\text { Tak } \\
\text { Seimbang } \\
\%\end{array}$ & 0 & 0 & 0 & 0 & 0 & 0 & 45,76 \\
\hline $\begin{array}{c}\text { Non } \\
\text { Linier }\end{array}$ & & & & & & & \\
\hline $\begin{array}{c}\text { Simulasi } \\
\text { Seimbang } \\
\%\end{array}$ & 1,49 & 1,47 & 1,48 & 16,38 & 16,31 & 16,19 & 61,62 \\
\hline $\begin{array}{c}\text { Simulasi } \\
\text { Tak } \\
\text { Seimbang } \\
\%\end{array}$ & 1,61 & 1,49 & 1,46 & 18,47 & 16,57 & 15,84 & 65,5 \\
\hline
\end{tabular}

Dari tabel di atas dapat dilihat hasil simulasi beban non linier THDv pada fasa R 1,49\% ; S 1,47\% ; T 1,48\% dan THDi pada fasa R $16,38 \%$; S 16,31\% ; T 16,19\%, sedangkan untuk beban non linier tak seimbang adalah THDv fasa $\mathrm{R}$ $1,61 \%$; S 1,49\%; T 1,46\% dan THDi fasa R 18,47\% ; S 16,57\% ; T 15,84\%. Pada simulasi beban linier baik seimbang atau tak seimbang tidak terdapat kandungan THDi danTHDv karena beban yang menghasilkan harmonisa adalah beban non linier.

Arus netral terbesar terjadi pada simulasi kondisi tak seimbang dengan beban non linier yaitu sebesar 65,5 A kemudian pada beban non linier seimbang arus netral yang mengalir adalah sebaesar 61,62 A. Pada beban linier tak simbang arus netral adalah 45,76 A dan pada beban linier seimbang besar arus netralnya adalah 0 . 


\section{B. Analisis THD Berdasarkan IEE 519 - 2014}

Berdasarkan IEEE 519-2014 diketahui bahwa standar $\mathrm{THD}_{\mathrm{V}}$ tegangan nominal di bawah $1 \mathrm{kV}$ yaitu sebesar $8 \%$. Hasil analisis perbandingan $\mathrm{THD}_{\mathrm{V}}$ dapat dilihat pada tabel 4 :

TABEL IV

ANALISIS THDV BERDASARKAN IEEE 519 - 2014

\begin{tabular}{|c|c|c|c|c|c|c|c|c|c|c|c|c|c|c|}
\hline Vol & \multicolumn{12}{|c|}{ THD Tegangan \% } & \multirow{3}{*}{$\begin{array}{c}\text { Stand } \\
\text { ar } \\
\text { IEEE } \\
519- \\
2014 \\
\text { THD } \\
\text { Tegan } \\
\text { gan } \\
\% \\
\end{array}$} & \multirow{3}{*}{$\begin{array}{c}\text { Ketera } \\
\text { ngan }\end{array}$} \\
\hline \multirow{4}{*}{$\begin{array}{l}\mathrm{V} \\
<1 \\
\mathrm{kV}\end{array}$} & \multicolumn{6}{|c|}{ Linier } & \multicolumn{6}{|c|}{ Non Linier } & & \\
\hline & & $\begin{array}{l}\text { nul } \\
\text { mba } \\
\%\end{array}$ & & & $\begin{array}{l}\text { Iula } \\
\text { ak } \\
\text { aba } \\
\%\end{array}$ & & & $\begin{array}{l}\text { imulas } \\
\text { imban }\end{array}$ & & & $\begin{array}{c}\text { ulasi } \\
\text { imban } \\
\%\end{array}$ & & & \\
\hline & $R$ & S & $\mathrm{T}$ & $\mathrm{R}$ & S & $\mathrm{T}$ & $\mathrm{R}$ & S & $\mathrm{T}$ & $\mathrm{R}$ & S & $\mathrm{T}$ & \multirow{2}{*}{8} & \multirow{2}{*}{$\begin{array}{l}\text { Sesuai } \\
\text { Standar }\end{array}$} \\
\hline & 0 & 0 & 0 & 0 & 0 & 0 & 1,49 & 1,47 & 1,48 & 1,61 & 1,49 & 1,46 & & \\
\hline
\end{tabular}

\section{Grafik perbandingan THDv simulasi Beban Linier}

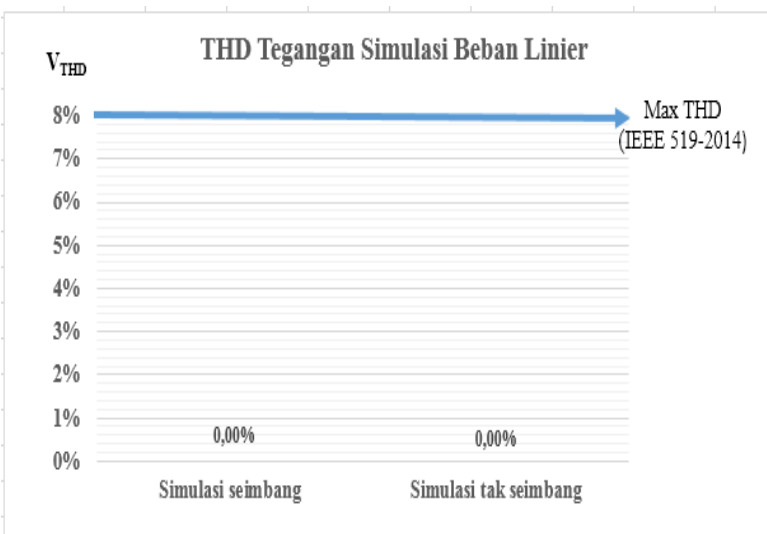

Gambar 17 Grafik Perbandingan THDv simulasi Beban Linier dengan IEEE 519-2014.

Grafik perbandingan THDv simulasi Beban Non Linier

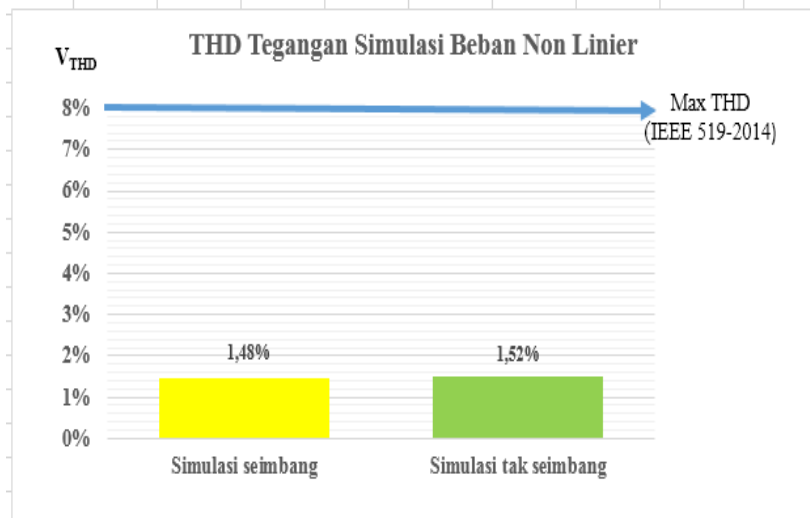

Gambar 18 Grafik Perbandingan THDv simulasi Beban Non Linier dengan IEEE 519-2014

Berdasarkan gambar grafik di atas diketahui bahwa THDv beban Linier dan Non Linier hasil simulasi seimbang dan tak seimbang pada tansformator 1 di RSUD Kabupaten Klungkung sesuai dengan standar IEEE 519-2014

Untuk menganalisis $\mathrm{THD}_{\mathrm{i}}$ perlu dihitung nilai $\mathrm{SC}_{\text {ratio }}$ terlebih dahulu. Diketahui bahwa arus hubung singkat yaitu 7,597 A dan Arus beban penuh yaitu 0,303 A sehingga $\mathrm{SC}_{\text {ratio }}$ pada transformator dapat dihitung sebagai berikut :

$$
\begin{aligned}
S c_{\text {ratia }} & =\frac{I_{\text {se }}}{I_{l}} \\
& =\frac{7.597 \mathrm{~A}}{0.303 \mathrm{~A}} \\
& =25.07
\end{aligned}
$$

Berdasarkan standar IEEE 519-2014, dengan $\mathrm{SC}_{\text {ratio }}$ sebesar 25,07 sehingga standar THDi yang digunakan sebesar $8 \%$. Hasil analisis perbandingan $\mathrm{THD}_{\mathrm{i}}$ berdasarkan standar IEEE 519-2014 dapat dilihat pada tabel 5 :

\begin{tabular}{|c|c|c|c|c|c|c|c|c|c|c|c|c|c|}
\hline \multirow[t]{3}{*}{$S C_{\text {ratio }}$} & \multicolumn{11}{|c|}{ THD Arus \% } & \multirow{3}{*}{$\begin{array}{c}\text { Stand } \\
\text { ar } \\
\text { IEEE } \\
519- \\
2014 \\
\text { THD } \\
\text { Arus } \\
\%\end{array}$} & \multirow{3}{*}{$\begin{array}{c}\text { Ketera } \\
\text { ngan }\end{array}$} \\
\hline & \multicolumn{5}{|c|}{ Linier } & \multicolumn{6}{|c|}{ Non Linier } & & \\
\hline & $\begin{array}{r}\text { Simu } \\
\text { Seim } \\
\mathbf{g} \\
\%\end{array}$ & & & $\begin{array}{l}\text { aulas } \\
\text { Cak } \\
\text { mba } \\
\text { g } \\
\%\end{array}$ & & & $\begin{array}{l}\text { Simulas } \\
\text { eimban } \\
\%\end{array}$ & & Simula & $\begin{array}{c}\mathrm{i} \text { Tak S } \\
\%\end{array}$ & imbang & & \\
\hline \multirow{2}{*}{25.01} & \begin{tabular}{l|l}
$R$ & $S$
\end{tabular} & $\mathrm{~T}$ & $\mathrm{R}$ & S & I & $\mathrm{R}$ & S & T & $\mathrm{R}$ & S & $\mathrm{T}$ & \multirow{2}{*}{8} & \multirow{2}{*}{$\begin{array}{c}\text { Tidak } \\
\text { Sesuai } \\
\text { Standar }\end{array}$} \\
\hline & \begin{tabular}{l|l}
0 & 0
\end{tabular} & 0 & 0 & 0 & 0 & 16,38 & 16,31 & 16,19 & 18,47 & 16,57 & 15,84 & & \\
\hline
\end{tabular}

TABEL V

ANALISIS THDI BERDASARKAN IEEE 519 - 2014

\section{Grafik perbandingan THDi simulasi Beban Linier}

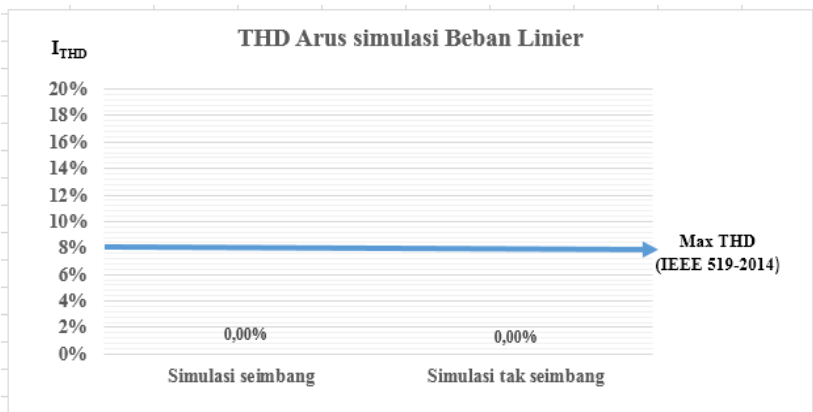

Gambar 19 Grafik Perbandingan THDi Beban Linier dengan IEEE 519-2014

Grafik perbandingan THDi simulasi Beban Non Linier

I Gusti Ngurah Dwipayana: Analisis THD dan Peningkatan Arus ...

p-ISSN:1693 - 2951; e-ISSN: 2503-2372 


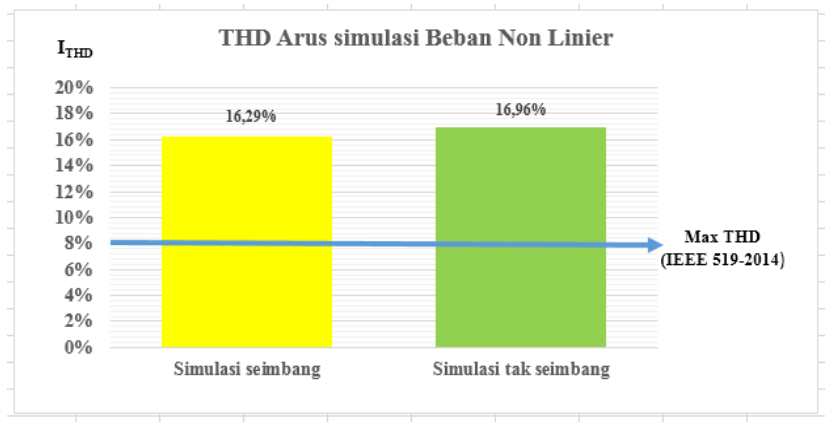

Gambar 20 Grafik Perbandingan THDi Beban Non Linier dengan IEEE 519-

2014.

Berdasarkan gambar grafik di atas diketahui bahwa THDi beban Linier dan Non Linier hasil simulasi seimbang dan tidak seimbang pada Transformator 1 di RSUD Kabupaten Klungkung tidak sesuai dengan standar IEEE 519-2014.

\section{KeSIMPULAN}

Dari hasil simulasi dan analisa yang telah dilakukan maka simpulan dapat diambil adalah: Ketidakseimbangan beban berpengaruh terhadap prosentase THD dan Arus netral. Pada kondisi seimbang dengan beban linier nilai arus netral adalah 0 . Pada kondisi tak seimbang dengan beban linier nilai arus netral adalah 45,76 A. Pada kondisi seimbang dengan beban non linier nilai arus netral 61,62 A dengan prosentase THDv pada fasa R 1,49\% ; S 1,47\% ; T 1,48\% dan THDi pada fasa R $16,38 \%$; S 16,31\% ; T 16,19\%. Pada kondisi tak seimbang dengan beban non linier terjadi peningkatan yaitu nilai arus netral 65,5 A dengan prosentase THDv pada fasa $\mathrm{R} 1,61 \%$; $\mathrm{S}$ $1,49 \%$; T 1,46\% dan THDi pada fasa R $18,47 \%$; S 16,57\% ; $\mathrm{T} 15,84 \%$.

\section{REFERENSI}

[1] Badarudin. 2012. Pengaruh Ketidakseimbangan Beban Terhadap Arus Netral Dan Losses Pada Trafo Distribusi Proyek Rusunami Gading Icon. Jakarta; Program Studi Teknik Elektro Fakultas Teknik Universitas Mercu Buana.

[2] Dugan, R.C., McGranaghan, M.F., Santoso, S., Beaty, H.W. 2004. Electrical Power System Quality-Second Edition. The McGraw-Hill.

[3] Gonen, T. 2008. Electric Power Distribution System Engineering, Second Edition. United States of America : CRC Press.

[4] IEEE Recommended Practices and Requirements for Harmonic Control in Electric Power Systems. IEEE Standard 519-2014.

[5] Nugraha, I.P. Wira. 2013. Simulasi pengaruh beban tak seimbang terhadap Total Harmonic Distortion (THD), Arus Netral dan Losses pada sistem tenaga listrik.

[6] Suryajaya, A. 2011. Pengaruh Total Harmonic Distortion (THD) Pada Suatu Sistem. Semarang ; Program Studi Teknik Elektro Jurusan Teknologi Industri Universitas Katolik Soegijapranata.

[7] Sudarto, A. 2006. Analisis Pengaruh Kawat Netral Terhadap Hilang Daya Di Saluran 3 Fase 4 Kawat Menggunakan Matlab 6.1. Yogyakarta: Jurusan Teknik Elektro Fakultas Teknik Universitas Gadjah Mada.

[8] Suweden, I.N., Rinas, I.W., 2012. Analisa Penanggulangan THD dengan Filter Pasif pada Sistem Kelistrikan di RSUP Sanglah. Maj . Ilm. Teknol. Elektro J. Electr. Technol. 8.

[9] Wicaksana, T. 2011. Analisa Arus Netral Pada Jaringan Tiga Fasa Empat Kawat beban Tak Linier. Semarang : Program Studi Teknik Elektro Fakultas Teknologi Industri Universitas Soegijapranata.

[10] Yoakim Simamora, Panusur S.M.L, Panusur S.M.L. Tobing 2010. Analisis Ketidakseimbangan beban transformator distribusi untuk identifikasi beban lebih dan estimasi rugi-rugi pada jaringan tegangan rendah. 